\title{
Pelatihan Mindfulness Teaching untuk Meningkatkan Kesejahteraan Subjektif Guru Sekolah Inklusi
}

\author{
Ulin Nuha Rahmawati, Fuad Nashori, Ratna S. Rachmahana \\ Fakultas Psikologi dan Ilmu Sosial Budaya, Universitas Islam Indonesia, Yogyakarta, Indonesia \\ e-mail: fuadnashori@uii.ac.id
}

\begin{abstract}
This study aimed to examine the effectiveness of mindfulness teaching training in improving the subjective well-being of teachers in an inclusive school in Yogyakarta. This research used nonrandomized pretest-posttest control group design. There were 22 respondents which divided into 11 respondents for treatment group and 11 respondents for control group. They were asked to complete a survey consists of the satisfaction with life scale (SWLS) and positive and negative scale (PANAS) before and after experiment. The results showed that there is a significant difference between the subjective well-being of inclusive school teachers group given mindfulness teaching training and that of the teachers in the teachers group without mindfulness teaching training. This finding indicates that mindfulness teaching training was effective to improve inclusive school teachers' subjective well-being.
\end{abstract}

Keywords: mindfulness teaching, subjective well-being, inclusive school teacher

\begin{abstract}
Abstrak
Penelitian ini bertujuan mengetahui pengaruh pelatihan mindfulness teaching terhadap kesejahteraan subjektif pada guru sekolah inklusi di Yogyakarta. Rancangan eksperimen yang digunakan dalam penelitian ini adalah non-randomized pretest-posttest control group design. Responden berjumlah 22 orang yaitu 11 orang pada kelompok perlakuan dan 11 orang pada kelompok kontrol. Pemilihan responden penelitian ini menggunakan teknik purposive sampling. Responden diminta untuk mengisi satisfaction with life scale (SWLS) serta positive and negative scale (PANAS) sebelum dan sesudah pemberian perlakuan. Hasil penelitian menunjukkan bahwa terdapat perbedaan skor kesejahteraan subjektif guru sekolah inklusi yang diberikan pelatihan mindfulness teaching dengan yang tidak. Temuan ini mengindikasikan bahwa pelatihan mindfulness teaching efektif untuk meningkatkan kesejahteraan subjektif pada guru di sekolah inklusi.
\end{abstract}

Kata Kunci: mindfulness teaching, kesejahteraan subjektif, guru sekolah inklusi

\section{Pendahuluan}

Pendidikan merupakan hak setiap anak bangsa. Hal ini sebagaimana terungkap dalam Undang-Undang Dasar 1945 pasal 31 ayat 1: "Setiap warga negara berhak memperoleh pendidikan". Setiap anak bangsa yang memiliki bakat dan kecerdasan yang luar biasa maupun anakanak yang memiliki disabilitas, seperti anak yang mengalami kesulitan belajar (learning disability), tunalaras, tunanetra, tunagrahita, tunarungu, tunadaksa, berhak atas pendidikan. Demikian juga anak-anak yang kondisi ekonomi keluarganya sangat minimal, anak-anak yang berada dan tinggal di daerah terpencil, maupun anakanak di daerah yang terkena bencana. Semuanya berhak atas pendidikan. Salah satu implikasi dari kondisi di atas adalah munculnya konsep pendidikan inklusi (Haryono dkk., 2019).

Pendidikan sekolah inklusi dimaksudkan untuk mengimplementasikan konsep education for all (pendidikan untuk semua). Semua manusia berhak atas pendidikan, tanpa diskriminasi dari siapapun. Dengan pendidikan yang diperolehnya, terbentang kesempatan bagi individu untuk mengem- 
bangkan berbagai potensi pribadinya (Astuti dkk., 2011). Pendidikan inklusi memberikan peluang bagi semua calon peserta pendidik di Indonesia, baik yang kondisinya normal maupun yang memiliki kebutuhan khusus.

Pendidikan inklusi merupakan bagian integral dari pendidikan untuk semua peserta didik mulai dari pendidikan sekolah dasar sampai dengan pendidikan sekolah menengah atas (Widiasti, 2013). Peraturan Menteri Pendidikan Nasional Nomor 70 Tahun 2009 mengatur bagaimana pendidikan sekolah inklusi itu diarahkan. Dalam peraturan ini dijelaskan bahwa: "Tujuan pendidikan inklusi adalah memberikan kesempatan yang sama kepada semua peserta didik yang memiliki kelainan fisik, emosional, mental, dan sosial atau kecerdasaan dan/ atau bakat istimewa untuk memperoleh pendidikan yang bermutu sesuai dengan kebutuhan dan kemampuannya". Kota Yogyakarta yang dikenal sebagai kota pendidikan memiliki komitmen yang tinggi untuk mengimplementasikan kebijakan nasional tentang pendidikan inklusi. Kota ini telah ditetapkan menjadi pusat pengembangan pendidikan inklusi di kawasan Asia Tenggara atau yang biasa disebut sebagai ASEAN. Di kota ini telah berkembang berbagai sekolah inklusi, terutama sekolah dasar.

Praktik sekolah inklusi memberikan tantangan bagi pihak manajemen sekolah maupun para guru. Pihak manajemen sekolah dituntut mampu menawarkan program pendidikan yang sesuai dan menyiapkan para guru agar mereka mampu memperlakukan anak-anak berkebutuhan khusus maupun anak-anak yang tidak berkebutuhan khusus secara optimal. Para guru perlu dipersiapkan untuk melakukan tugas-tugas mereka dengan sebaik-baiknya. Hal ini sebagaimana dipesankan dalam Undang-Undang Nomor 14 Tahun 2004 bahwa "Guru adalah tenaga profesional berfungsi untuk mendidik, mengajar, membimbing, mengarahkan, melatih, menilai, dan mengevaluasi peserta didik dan meningkatkan martabat dan peran sebagai agen pembelajaran yang berfungsi untuk meningkatkan mutu pendidikan". Dari definisi tersebut tampak bahwa guru memiliki tugas sentral dalam pendidikan formal, yang mana guru menjadi ujung tombak pendidikan. Oleh karena itu, penting bagi seorang guru harus memiliki karakteristik pribadi, sosial dan profesional yang stabil dalam melaksanakan tugas yang telah diberikan. Sebagai contoh, sebagaimana disampaikan Widiasmara dkk. (2013), guru yang memiliki pengetahuan yang baik tentang tugas-tugasnya sebagai guru sekolah inklusi akan memudahkan mereka dalam menjalankan tugas-tugas.

Faktanya masih ada sejumlah guru yang mengeluhkan tentang kebijakan dari Dinas Pendidikan dan memiliki tuntutan yang berbeda dengan guru yang berada di sekolah reguler. Para pendidik reguler yang telah terbiasa mendidik anak normal merasa kesulitan dan menjadi salah satu penghambat akan kesuksesan praktik pendidikan inklusi. Selain itu para pendidik memiliki sikap negatif terhadap potensi pada anak berkebutuhan khusus (ABK). Beberapa guru yang telah diwawancarai mengaku bahwa mereka sering merasa sedih, ingin mengeluh, sulit mengontrol emosi, merasa tertekan bahkan sering menjadi serba salah. Masalah berikutnya yang secara sistematis dihadapi oleh guru adalah masalah perubahan kurikulum. Guru diwajibkan mampu memahami dan mengimplementasikan kurikulum secara utuh agar anak-anak yang memiliki kebutuhan khusus memperoleh pendidikan secara optimal. Namun, pada kenyataannya masih terdapat sejumlah guru di sekolah inklusi tidak mampu berpartisipasi dengan optimal dalam mendidik anak yang mempunyai kebutuhan khusus dan lebih cenderung hanya mengajar anak yang tidak memiliki kebutuhan khusus. Hal tersebut disebabkan beban mengajar untuk anak berkebutuhan khusus dipersepsikan lebih berat dibandingkan mengajar anak yang 
tidak memiliki kebutuhan khusus (Stark dkk., 2011).

Berdasarkan paparan di atas dapat disimpulkan bahwa sumber daya guru merupakan salah satu kendala dalam implementasi pendidikan inklusi. Penerbitan berbagai aturan dari Dinas Pendidikan ke sekolah-sekolah memengaruhi kondisi psikologis para guru. Para guru memiliki berbagai persepsi terkait dengan $\mathrm{ABK}$, penerimaan siswa ABK, serta memiliki perasaan yang beragam dalam menghadapi siswa ABK. Persepsi terhadap pengalaman hidup yang terdiri dari evaluasi afektif dan kognitif termasuk salah satu aspek dari kesejahteraan subjektif (Ariati, 2010).

Masalah lain yang dihadapi para guru di sekolah inklusi adalah perilaku siswa yang tidak sesuai, kedisiplinan siswa, motivasi belajar siswa yang rendah, beban kerja guru yang berat, tekanan waktu, tekanan dan konflik dengan staf di sekolah, tekanan serta kritik dari orang tua wali murid. Guru mendapati adanya tuntutan serta tekanan yang cenderung lebih besar saat mengajar pada sekolah inklusi. Pemahaman mereka tidak berbanding lurus dengan keterampilan yang mereka miliki dalam mendidik anak-anak yang memiliki kebutuhan khusus.

Peneliti telah mewawancarai beberapa guru sekolah inklusi di Kota Yogyakarta untuk memperoleh gambaran mengenai tantangan sebagai guru dan mengenai pekerjaan sebagai guru di sekolah inklusi. $\mathrm{E}$ (perempuan, 45 tahun) mengungkapkan bahwa beban kerja sebagai guru di sekolah inklusi berbeda dengan di sekolah biasa.

"Ada beberapa perbedaan ketika saya mengajar di sekolah biasa terdahulu dengan saya mengajar di sekolah yang sekarang. Beban kerja di sekolah sekarang lebih berat dan tantangan untuk kita lebih kreatif. Terutama untuk siswa yang lambat dalam memahami pelajaran. Saya juga harus lebih ekstra dalam memberikan pengajaran selama pelajaran berlangsung. Dari segi emosional saya juga harus bisa menempatkan diri tetapi terkadang saya masih suka marah-marah dan berdampak pada kesehatan fisik saya, mbak. Beberapa minggu yang lalu suara saya sempat hilang."

Hal serupa juga diungkapkan oleh B (perempuan, 48 tahun) yang bekerja sebagai guru di sekolah inklusi. B menceritakan bahwa guru-guru di sekolah inklusi memiliki tuntutan yang cukup berat dibandingkan dengan guru di sekolah reguler. Guru diminta untuk mampu memberikan pengajaran yang sesuai dengan kebutuhan anak tersebut, lebih kreatif dalam memberikan materi kepada siswa yang berkebutuhan khusus, memiliki program individu, serta mampu memberikan kelas remedial bagi siswa yang memiliki kriteria tertentu.

"Di sekolah inklusi ada beban yang cukup berat bagi guru. Kita dituntut untuk mampu memberikan pengajaran yang berbeda-beda yang sesuai kepada siswa. Sesuai dengan kebutuhan mereka saja itu sudah cukup melelahkan, apalagi kita dituntut untuk lebih kreatif dalam memberikan materi, memberikan program yang sesuai dan saat siswa yang memiliki kriteria lamban belajar, kita harus bisa memberikan pengajaran tambahan di luar kelas. Belum lagi dengan adanya tuntutan lainnya, ya bisa dibayangkan semuanya memerlukan tenaga dan pikiran. Saya terkadang kurang bisa mengontrol emosi kepada anak-anak yang berkebutuhan khusus seperti saya suka bersuara dengan nada agak tinggi, marah-marah saat mengajar berlangsung, saya harus mengeluarkan tenaga ekstra untuk mereka, apalagi dalam pembelajaran yang berkaitan dengan pemahaman. Terkadang saya setelah saya marah atau bernada tinggi ada perasaan bersalah pada diri saya yang di mana saya masih kurang mampu menangani 
dan mengetahui strategi yang tepat bagi anak ABK dan berdampak demikian."

Masalah yang dihadapi oleh seorang guru saat ini dapat menimbulkan efek, yaitu munculnya afek negatif maupun menurunnya afek positif (Boniwell \& Ryan, 2012). Afek positif merujuk pada perasaan nyaman, bersemangat dan positif. Sedangkan afek negatif merujuk pada adanya ketegangan dan ketidaknyamanan sebagai akibat dari berbagai macam rasa tidak nyaman, seperti marah, dihina, dibenci dan perasaan bersalah, takut dan gelisah (Hefferon \& Boniwell, 2011). Keadaan di atas menggambarkan apa yang disebut sebagai kesejahteraan subjektif. Menurut Diener dkk. (2003), kesejahteraan subjektif adalah sebagai persepsi seseorang serta hasil evaluasinya terhadap afeksi diri sendiri yang termasuk di dalamnya reaksi terhadap suatu hal sebagai hasil pemikiran terhadap kepuasaan dan kebahagiaan. Kesejahteraan subjektif terdiri atas dua aspek, yaitu afektif dan aspek kognitif. Aspek afektif meliputi tingginya emosi positif dan rendahnya emosi negatif. Aspek kognitif merujuk pada penilaian yang diberikan individu atas kualitas hidup secara menyeluruh. Hasil penilaian adalah kepuasan hidup.

Untuk mengatasi munculnya berbagai emosi negatif dan mendorong peningkatan emosi positif guru diperlukan adanya intervensi. Intervensi tersebut diharapkan dapat meningkatkan kesejahteraan subjektif pada guru di sekolah inklusi. Guru yang memiliki kesejahteraan subjektif yang tinggi ditandai oleh adanya emosi-emosi positif dan rendahnya emosi-emosi negatif. Menurut Stanculescu (2014), guru yang memiliki pengalaman emosional negatif perlu memperoleh intervensi secara psikologis untuk dapat meningkatkan kesejahteraan subjektif mereka. Kesejahteraan subjektif yang tinggi pada guru akan menghasilkan dampak pada siswa, yaitu membuat individu lebih nyaman saat mengajar siswa di sekolah. $\begin{array}{crrr}\text { Ada } & \text { sejumlah } & \text { intervensi yang } \\ \text { digunakan } & \text { untuk } & \text { meningkatkan }\end{array}$ kesejahteraan subjektif. Penelitian yang dilakukan oleh Anggarani dkk. (2013) mencoba untuk mengetahui pengaruh pelatihan syukur terhadap peningkatan kesejahteraan subjektif pada penduduk miskin. Pelatihan tersebut mengarahkan subjek penelitian kepada perilaku bersyukur sehingga mereka dapat menggali sisi positif yang ada dalam diri mereka di tengah situasi yang serba minus sehingga terhindar dari perasaan negatif. Pelatihan memberikan pemahaman dan keterampilan untuk mengenali kebaikan-kebaikan yang telah diterima sehingga dapat meningkatkan rasa syukur. Hasil penelitian menunjukkan bahwa pelatihan bersyukur efektif dalam meningkatkan kesejahteraan subjektif pada penduduk miskin. Keterbatasan penelitian tersebut adalah sedikitnya jumlah peserta yang bersedia mengikuti pelatihan yang berdampak pada hasil penelitian tersebut rentan tidak menggambarkan populasi yang ada. Selain itu, hasil penelitian tersebut terbatas pada kelompok miskin dan belum terkait langsung dengan guru sekolah inklusi.

Selanjutnya kesejahteraan subjektif individu dipengaruhi oleh dukungan sosial. Hal ini ditunjukkan oleh riset Thohirah dkk. (2019) bahwa kesejahteraan subjektif yang dirasakan subjek didik dipengaruhi oleh persepsinya terhadap dukungan sosial yang diterima. Semakin tinggi persepsi siswa bahwa guru, orang tua, dan teman mendukungnya, maka semakin tinggi pula kepuasan hidup serta afek positif, dan semakin rendah afek negatif mereka.

Nashori dkk. (2019) menunjukkan bahwa kesejahteraan subjektif subjek dipengaruhi oleh terapi kognitif perilakuinsomnia (insomnia-cognitive behavior therapy). Ketika mahasiswa mendapatkan terapi kognitif perilaku-insomnia, kesejahteraan subjektif mereka meningkat, dalam hal ini adalah meningkatkan afek positif dan menurunkan afek negatif. Keterbatasan penelitian tersebut, subjek penelitian adalah 
subjek didik (dalam hal ini mahasiswa), dan bukan fasilitator pendidikan seperti guru atau dosen.

Intervensi yang dimaksudkan untuk meningkatkan kesejahteraan subjektif juga dilakukan dengan menggunakan pelatihan empathic love therapy. Penelitian yang dilakukan oleh Rosada (2015) dimaksudkan untuk mengetahui efektivitas terapi cinta empatik dalam mengakselerasi kesejahteraan subjektif guru di sekolah inklusi. Pelatihan emphatic love therapy adalah serangkaian pelatihan dengan pendekatan transpersonal yang diberikan sebagai proses pengenalan diri sendiri (self). Hasil penelitian menunjukkan bahwa emphatic love therapy efektif meningkatkan kesejahteraan subjektif.

Intervensi berikutnya dalam upaya meningkatkan kesejahteraan subjektif guru adalah pelatihan mindfulness. Saat ini, sebagaimana diungkapkan Black dkk. (2009), sudah semakin banyak penelitian yang mengaitkan mindfulness berbasis bidang pendidikan atau sekolah yang melibatkan berbagai tingkat pelatihan untuk guru sekolah. Hasil penelitian yang dilakukan Beshai dkk. (2015) menunjukkan bahwa pelatihan mindfulness pada guru telah terbukti secara empiris mampu meningkatkan kesejahteraan subjektif guru. Berbagai aktivitas dalam kegiatan mindfulness teaching, seperti meditasi, mampu menurunkan tingkat stres, sering diikuti dengan munculnya pengalaman kedamaian dari dalam diri, penghargaan atas diri, serta meningkatkan kesejahteraan (McGarrigle \& Waish, 2011). Selain itu, menurut Brown dan Ryan (dalam Maharani, 2016), berbagai penelitian telah menunjukkan bahwa mindfulness berkorelasi dengan emosi positif, kesejahteraan emosi, peningkatan kemampuan dalam regulasi emosi serta kesejahteraan diri. Selain itu ditemukan pula mindfulness berkorelasi dengan behavioral self-control (Rahman dkk., 2019). Di sisi yang lain, studi juga menunjukkan bahwa pelatihan mindfulness pada guru secara empiris mampu mengurangi perasaan reaktif, mudah marah, ataupun terprovokasi (Keng dkk., 2011), mengurangi stres atau tekanan terkait pekerjaan (Beshai dkk., 2015).

Berdasarkan penjelasan di atas, dapat dirumuskan tujuan penelitian ini, yaitu mengetahui efektivitas pelatihan mindfulness teaching dalam meningkatkan kesejahteraan subjektif guru sekolah inklusi di Yogyakarta. Adapun hipotesis yang diajukan dalam penelitian ini adalah ada perbedaan kesejahteraan subjektif antara kelompok yang diberikan perlakuan berupa pelatihan mindfulness teaching dengan kelompok yang tidak diberikan perlakuan.

\section{Metode Penelitian}

Penelitian ini menggunakan pendekatan kuantitatif eksperimental yang didukung oleh pendekatan kualitatif. Rancangan eksperimen menggunakan nonrandomized pretest-posttest control group design (Myers \& Hansen, 2002). Dalam desain ini terdapat dua kelompok, yaitu kelompok perlakuan dan kelompok kontrol. Perlakuan yang diberikan kepada kelompok perlakuan adalah pelatihan mindfulness teaching. Pengaruh atau efek dari perlakuan diukur dengan membandingkan perbedaan skor nilai prates dan pasca-tes pada kelompok perlakuan maupun kelompok kontrol.

Pemilihan responden menggunakan teknik purposive sampling. Responden adalah guru Sekolah Dasar sekolah inklusi $\mathrm{X}$ dan Y di Yogyakarta, berjenis kelamin laki-laki dan perempuan, berusia dewasa awal dan dewasa tengah (25-58 tahun), berpendidikan minimal diploma, dan memiliki skor kesejahteraan subjektif pada kategori sedang dan rendah. Jumlah responden sebanyak 22 guru SD dari dua sekolah yang berbeda, terdiri dari 11 orang guru pada kelompok perlakuan dan 11 orang guru pada kelompok kontrol.

Metode pengumpulan data menggunakan skala kesejahteraan subjektif yang telah divalidisi oleh Utami (2009). Skala tersebut mengukur aspek kepuasan hidup, afek positif, serta afek negatif yang terdiri atas 
dua bagian skala, yaitu bagian pertama, sebanyak 5 item mengukur kepuasan hidup, statisfaction with life scale (SWLS) sementara bagian kedua mengukur evaluasi afek positif dan negatif atau positive and negative affect schedule (PANAS) yang terdiri atas 29 item kata-kata yang menunjukkan emosi negatif dan 27 item kata-kata menunjukkan emosi positif yang digabungkan dan urutannya diacak. Menurut Pavot dan Diener (1993), disusun subskala kepuasaan hidup (SWLS). Mengacu pada Watson dkk. (1988), disusun subskala afek. Subskala afek positif dan negatif (PANAS) digunakan untuk memeriksa kondisi emosi seseorang yang merupakan refleksi dari dimensi kecenderungan.

Koefisien validitas skala kepuasan hidup bergerak dari angka .451 - .777, sedangkan koefisien validitas skala afek positif dan negatif bergerak dari .347 .680. Koefisien reliabilitas skala kesejahteraan subjektif pada subskala kepuasaan hidup menunjukkan nilai sebesar .749, subskala afek positif sebesar .918, subskala afek negatif sebesar .941, sedangkan skor reliabilitas dari ketiga subskala tersebut sebesar .9352 .

Intervensi yang diberikan berupa pelatihan mindfulness teaching dengan menggunakan acuan modul pelatihanpelatihan sebelumnya. Pertama, mengacu pada modul pelatihan mindfulness bagi guru honorer dikembangkan oleh Nugraheni (2017) dan modul pelatihan mindfulness teaching untuk guru di sekolah inklusi yang dikembangkan oleh Marsidi (2011). Adapun konsep yang digunakan dalam modul ini berasal dari mindfulnessbased stress reduction (MBSR) dan mindfulness-based cognitive therapy (MBCT) (Crane, 2009; Didonna, 2009; Kabat-Zinn, 2005). Modul mindfulness bagi guru di sekolah inklusi merupakan materi pelatihan yang disusun berdasarkan terapi mindfulness dengan mengajarkan mengenai teknik-teknik serta sikap dari mindfulness itu sendiri. Tujuan pelatihan mindfulness bagi guru sekolah inklusi pada modul ini, yakni mengembangkan emosi positif, menurunkan afek negatif, dan meningkatkan kepuasan hidup dalam mengajar anak-anak ABK.

Pelatihan mindfulness teaching ini terdiri atas tiga kali pertemuan yang terbagi menjadi tiga sampai empat sesi di setiap pertemuan. Setiap pertemuan membutuhkan waktu 2-3 jam. Pelaksanaan pelatihan ini dilakukan dengan beberapa sesi yaitu: (1) Pembukaan dan perkenalan, (2) Membuka pengalaman, (3) Berkenalan dengan mindfulness, (4) Meditasi tubuh dan penghargaan, (5) Mengenali hasrat, (6) Melepaskan hasrat, (7) Merasakan berbagi, (8) Konsep kesadaran, pengalaman saat ini, penerimaan dalam kehidupan sehari-hari, (9) Mengenal inklusi, (10) Mengenali dan saran praktis mengajar ABK, (11) Mengenali Program Pembelajaran Individual ABK, dan (12) Penutup. Pelatihan ini mengukur aspek kognitif dan afektif. Pelatihan ini menggunakan metode ceramah, diskusi, sharing, praktek dan tayangan film pendek.

Analisis data kuantitatif dilakukan dengan menggunakan analisis Friedman. Hal ini bertujuan untuk mengetahui perbedaan skor prates dan pascates pada kelompok perlakuan dan kelompok kontrol. Sementara analisis data kualitatif dalam didapatkan pada saat awal melakukan penelitian melalui wawancara dan observasi. Hal tersebut bermaksud untuk memperoleh pernyataan langsung (direct quotation) dari responden penelitian mengenai perubahan yang dialami selama proses pelatihan berlangsung.

\section{Hasil Penelitian dan Pembahasan}

Hipotesis pada penelitian ini adalah terdapat perbedaan skor kesejahteraan subjektif pada kelompok perlakuan dan kelompok kontrol. Kelompok perlakuan diberikan perlakuan berupa pelatihan mindfulness teaching dan kelompok kontrol tidak mendapatkan perlakuan. 
Tabel 1 menyajikan hasil bahwa terdapat perubahan yang signifikan pada pengukuran prates dan pascates setelah diberikan perlakuan berupa pelatihan mindfulness teaching pada kelompok perlakuan. Sementara itu, pada kelompok kontrol tidak ada perubahan yang signifikan pada pengukuran prates dan pascates. Dengan demikian, dapat disimpulkan bahwa kelompok perlakuan mengalami peningkatan kesejahteraan subjektif dan kelompok kontrol tidak mengalami peningkatan. Secara keseluruhan dapat disimpulkan bahwa pelatihan mindfulness teaching dapat meningkatkan kesejahteraan subjektif pada guru sekolah inklusi dalam mengontrol emosi guru selama mengajar siswa ABK.

Tabel 1.

Hasil Uji Friedman Kelompok Perlakuan dan Kelompok Kontrol

\begin{tabular}{lcccc}
\hline & Chi- & & & \\
\multicolumn{1}{c}{ Kelompok } & Square & $\mathrm{P}$ & $\mathrm{N}$ & Ket. \\
\hline Perlakuan & 9.814 & .007 & 11 & Signifikan \\
Kontrol & 2.909 & .234 & 11 & $\begin{array}{c}\text { Tidak } \\
\text { Signifikan }\end{array}$ \\
\hline
\end{tabular}

Tabel 2

Hasil Uji Friedman setiap Aspek Kesejahteraan Subjektif pada Kelompok Perlakuan

\begin{tabular}{lccc}
\hline \multicolumn{1}{c}{ Aspek } & $\begin{array}{c}\text { Chi- } \\
\text { Square }\end{array}$ & $\mathrm{P}<.05$ & Keterangan \\
\hline Kepuasan hidup & 1.950 & .377 & $\begin{array}{c}\text { Tidak } \\
\text { Signifikan } \\
\text { Afek positif }\end{array}$ \\
Afek negatif & 7.951 & .019 & $\begin{array}{l}\text { Signifikan } \\
\text { Signifikan }\end{array}$ \\
\hline
\end{tabular}

Tabel 3

Hasil Uji Friedman setiap Aspek Kesejahteraan Subjektif pada Kelompok Kontrol

\begin{tabular}{|c|c|c|c|}
\hline Aspek & $\begin{array}{c}\text { Chi- } \\
\text { Square }\end{array}$ & $\mathrm{P}<.05$ & Ket. \\
\hline Kepuasan hidup & 3.857 & .145 & $\begin{array}{c}\text { Tidak } \\
\text { Signifikan }\end{array}$ \\
\hline Afek positif & 3.707 & .157 & $\begin{array}{c}\text { Tidak } \\
\text { Signifikan }\end{array}$ \\
\hline Afek negatif & 2.909 & .234 & $\begin{array}{c}\text { Tidak } \\
\text { Signifikan }\end{array}$ \\
\hline
\end{tabular}

Tabel 2 menunjukkan bahwa dua aspek kesejahteraan subjektif yaitu afek positif dan afek negatif pada kelompok perlakuan secara signifikan mengalami perubahan setelah diberikan pelatihan mindfulness teaching. Sedangkan satu aspek yaitu kepuasan hidup dalam skala kesejahteraan subjektif tidak mengalami perubahan setelah diberikan pelatihan mindfulness teaching. Tabel 3 menunjukkan bahwa semua aspek kesejahteraan subjektif, baik aspek kepuasan hidup, afek positif, maupun afek negatif pada kelompok kontrol tidak signifikan.

Tujuan penelitian ini adalah mengetahui efektivitas pelatihan mindfulness teaching dalam meningkatkan kesejahteraan subjektif guru sekolah inklusi. Hasil penelitian ini menunjukkan bahwa kelompok perlakuan yang menerima pelatihan mindfulness teaching mengalami peningkatan kesejahteraan subjektif pada guru sekolah inklusi dengan nilai signifikansi sebesar $.007 \quad(\mathrm{p}<.01)$. Sementara kelompok kontrol yang tidak menerima pelatihan mindfulness teaching tidak mengalami peningkatan dalam hal kesejahteraan subjektif. Secara khusus, hasil penelitian menunjukkan adanya perubahan pada aspek afek positif dan afek negatif. Terjadi perubahan afek positif yang cenderung meningkat dan penurunan pada afek negatif. Sementara pada aspek kepuasan hidup, secara statistik responden tidak mengalami peningkatan kepuasan hidup setelah diberikan pelatihan mindfulness teaching.

Hasil penelitian ini mendukung pendapat dan hasil penelitian sebelumnya. Keng dkk. (2011) mengungkapkan bahwa mindfulness mampu meningkatkan pengalaman dengan afek positif dan menurunkan pengalaman dengan afek negatif dan kemampuan yang lebih baik dalam merespon peristiwa yang penuh dengan tekanan. Pendapat tersebut sejalan dengan hasil penelitian Hartnett dkk. (2010), bahwa pelatihan mindfulness singkat dapat meningkatkan kesejahteraan 
subjektif pada individu. Berbagai penelitian menunjukkan bahwa pelatihan mindfulness pada guru telah terbukti secara empiris mampu meningkatkan kesejahteraan subjektif guru (Beshai dkk., 2015; Hue \& Lau, 2015; Poulin dkk., 2008). Menurut Brown dan Ryan (Maharani, 2016), berbagai penelitian di atas telah menunjukkan bahwa mindfulness berkorelasi dengan emosi positif, kesejahteraan emosi, peningkatan kemampuan dalam regulasi emosi serta kesejahteraan diri. Selanjutnya penelitian yang dilakukan oleh Haryono dkk. (2019) dengan judul pendidikan bagi anak berkebutuhan khusus dengan pendekatan mindfulness teaching. Hasil penelitian menunjukkan para pendidik mampu menerapkan mindfulness teaching untuk mengontrol emosinya dan menyadari kondisi anak secara komprehensif.

Hasil wawancara yang dilakukan kepada responden dapat menjelaskan bagaimana pelatihan mindfulness teaching dapat mengantarkan mereka meningkat kesejahteraan subjektifnya. Tahapan pertama yang adalah teknik menyadari pernafasan (breathing meditation). Tonnatto (dalam Khairani, 2007) menyatakan bahwa latihan pernapasan sebagai salah satu tahap yang mampu mencegah individu dari kesalahan berpikir dan mengurangi reaksi impulsif dalam merespon sesuatu.

Teknik kedua dan ketiga dari teknik mindfulness adalah menyadari sensasi tubuh (body sensation) dan pendeteksian tubuh (compassionate body sensation). Teknik menyadari sensasi tubuh bertujuan untuk melatih responden fokus pada sensasi tubuh sehingga perhatian responden dapat teralihkan dari perasaan tertekan dan stres atas sakitnya tersebut. Setelah mempraktikkan teknik ini, responden merasa bahwa mereka lebih dapat menghargai diri sendiri dan dapat mengalihkan rasa sakit yang sedang dirasakannya. Responden juga merasa lebih menghargai apa yang dimiliki oleh diri mereka. Teknik penerimaan dan penghargaan pada tubuh juga sangat berpengaruh pada kondisi responden. Responden merasa lebih dapat menghargai dan lebih memaknai secara lebih positif apa yang telah dialami.

Teknik terakhir yang dilatih dalam pelatihan adalah mindfulness dalam kehidupan sehari-hari. Teknik ini mengajarkan responden untuk mengobservasi kegiatan sehari-hari. Adanya perhatian dan fokus terhadap apa yang dilakukan sehari-hari akan membuat pasien menyadari dan dapat mengantisipasi setiap akibat dan manfaat dari pilihannya terhadap diri sendiri maupun orang lain.

Berdasarkan pemaparan di atas diketahui bahwa mindfulness memiliki dampak positif terhadap aspek kesejahteraan responden, khususnya terhadap menurunnya kekhawatiran individu tersebut. Mindfulness juga memiliki dampak positif terhadap aspek kekhawatiran sosial maupun pekerjaan, sehingga mereka dapat memaknai kondisi saat ini dengan lebih optimis. Keberhasilan pelatihan mindfulness didukung oleh antusiasme dari peserta dan penerimaan diri yang optimal dari peserta, disebabkan pelatihan yang diikuti tersebut belum pernah mereka ikuti sebelumnya. Hasil evaluasi pelatihan menunjukkan bahwa secara keseluruhan peserta memberikan penilaian sangat positif terhadap pelatihan ini. Mereka mengungkapkan bahwa pelatihan ini sangat bermanfaat dan mampu menambah ilmu baru bagi peserta pelatihan. Peserta juga mulai untuk menerapkan dan mengaplikasikan teknik mindfulness ini dalam kehidupan seharihari.

Berkaitan dengan kepuasan hidup, seorang individu yang berlatih mindfulness setiap saat akan mengalami peningkatan penerimaan terhadap diri sendiri. Menurut Durayappah (2010), kesejahteraan subjektif dapat dipengaruhi oleh evaluasi masa lalu, pengalaman saat ini, dan harapan yang akan datang. Sedangkan teknik mindfulness 
merupakan salah satu upaya membantu setiap orang untuk memiliki sepenuhnya pengalaman masa kini, melepaskan pengalaman masa lalu yang tidak menyenangkan dan mengembangkan sikap terbuka terhadap yang akan datang (KabattZinn, 2009).

Hasil penelitian ini menunjukkan bahwa terdapat peningkatan kesejahteraan subjektif guru pada kelompok perlakuan setelah diberikan pelatihan mindfulness teaching. Sedangkan pada kelompok kontrol tidak mengalami peningkatan sebab tidak diberikan pelatihan. Hasil penelitian yang signifikan juga dipengaruhi oleh metodologi. Secara metodologis, diantaranya dipengaruhi oleh pemilihan responden, rancangan eksperimen, alat ukur, dan kegiatan pelatihan. Dalam hal pemilihan responden penelitian, responden mengikuti pelatihan secara sukarela dan tidak ada paksaan. Hasil observasi yang telah dilakukan selama pelatihan didapatkan bahwasanya responden yang mengikuti pelatihan mengalami perubahan dalam mengelola emosi.

Pada rancangan penelitian ini digunakan kelompok kontrol dari sekolah yang sama sebagai pembanding kelompok perlakuan. Hasil penelitian juga tidak terlepas dari kegiatan pelatihan mindfulness teaching yang menerapkan pendekatan experiential learning. Pelatihan memuat berbagai kegiatan aktif seperti metode presentasi, video, games dan pengerjaan tugas yang mendorong responden untuk berlatih mengekspresikan dan mengelola emosinya. Pelatihan juga didukung dengan pemberian tugas rumah kepada responden penelitian untuk mempraktikkan mindfulness selama berada di rumah maupun sekolah. Silberman dan Biech (2015) mengemukakan bahwa experiential learning adalah keterlibatan peserta pelatihan dalam kegiatan belajar yang konkret membuat para peserta mampu untuk mengalami apa yang sedang dipelajari, baik dengan cara melihat, mendengar, bertanya, berdiskusi dan mempraktikkannya pada saat pelatihan maupun setelah pelatihan.

Secara keseluruhan, responden mampu mengikuti seluruh rangkaian pelatihan dengan baik sehingga dapat menurunkan afek negatif yang ada di dalam diri responden dan lebih memahami strategi pembelajaran bagi anak ABK. Hasil dari latihan yang dilakukan oleh responden menunjukkan bahwa responden memahami materi yang diberikan baik pada saat sesi di sekolah maupun di rumah.

Berdasarkan hasil-hasil penelitian, mindfulness telah banyak dikembangkan dalam berbagai setting kehidupan yaitu: mindfulness parenting, mindfulness birthing, mindfulness learning hingga mindfulness selling. Semua praktik mindfulness ini mengelaborasikan prinsipprinsip dasar mindfulness ke dalam bentukbentuk yang lebih spesifik. Pada ranah pendidikan, praktik mindfulness juga dapat dikembangkan dalam konteks hubungan guru-siswa melalui mindfulness teaching. Menggabungkan mindfulness ke dalam interaksi guru-siswa memberikan kesempatan pada guru untuk melihat pengalaman saat ini dengan siswa sebagai bentuk hubungan jangka panjang yang di dalamnya terdapat pemahaman akan kebutuhan anak, pengembangan sikap regulasi diri, serta pembuatan keputusan yang bijak dan berorientasi pada anak (child-oriented). Dalam level eksperimental, melalui model mindfulness teaching, guru dapat menghindarkan diri dari sikap reaktif, mengutamakan kebutuhan anak dibanding kebutuhan sendiri, menerima semua siswa sebagaimana adanya tanpa penilaian 'baikburuk', dan mampu mengatasi perasaan tertekan yang mungkin dialami dalam proses pembelajaran.

\section{Simpulan}

Hasil penelitian menunjukkan bahwa pelatihan mindfulness teaching efektif untuk meningkatkan kesejahteraan subjektif pada guru di sekolah inklusi. Ada 
perbedaan yang signifikan dalam hal kesejahteraan subjektif antara kelompok perlakuan yang diberikan pelatihan mindfulness teaching dan kelompok kontrol yang tidak diberikan pelatihan. Kelompok perlakuan meningkat kesejahteraan subjektifnya setelah mengikuti pelatihan mindfulness teaching, terutama pada aspek afek positif dan afek negatif.

\section{Daftar Pustaka}

Anggarani, K. F., Andayani, R. T., \& Karyanta, A. N. (2013). Pengaruh pelatihan syukur terhadap subjective well-being pada penduduk miskin di Surakarta. Jurnal Candrajiwa Program Studi Psikologi Fakultas Kedokteran UNS, 2(2), 44-59.

Ariati, J. (2010). Subjective well being (kesejahteraan subjektif) dan kepuasan kerja pada staf pengajar (dosen) di lingkungan Fakultas Psikologi Universitas Diponegoro. Jurnal Psikologi Undip, 8(2), 117-123. https://doi.org/10.14710/jpu.8.2.117123

Astuti, I., Sonhadji, Bafadal, I., \& Soetopo, H. (2011). Kepemimpinan pembelajaran sekolah inklusi. Bayu Media.

Beshai, S., McAlpine, L., Weare, K., \& Kuyken, W. (2015). A non-randomised feasibility trial asessing the efficacy of a mindfulness-based intervention for teachers to reduce stress and improve well-being. Mindfulness, 7(1), 198208. https://doi.org/10.1007/s12671015-0436-1

Black, D. S., Milam, J., \& Sussman, S. (2009).

Sitting-meditation interventions among youth: A review of treatment efficacy. Pediatrics. 124(3), 532-541. https://doi.org/10.1542/peds.20083434

Boniwell, I., \& Ryan, L. (2012). Personal well-being: Lessons for secondary schools, positive psychology in action for 11 to 14 year olds. Open University Press, McGraw-Hill Education.

Chang, W. C. (2009). Religious attendance and subjective well-being in an eastern-culture country: Empirical evidence from Taiwan. Marburg Journal of Religion, 4(1), 1-24. https://doi.org/10.17192/mjr.2009.14.3 465

Crane, R. (2009). Mindfulness-based cognitive therapy: Distinctive features. Routledge/Taylor and Francis Group.

Diener, E., Oishi, S., \& Lucas, R. E. (2003). Personality, culture, and subjective well-being: Emotional and cognitive evaluations of life. Annu. Rev. Psychol.. 5, 403-25.

Diener, E., Lucas, R. E., \& Oishi, S. (2005). Subjective well being: The science of happiness and life satisfaction. Handbook of Positive Psychology. 63-73. Oxford University Press.

Didonna, F. (2009). Clinical handbook of mindfulness. Springer.

Durayappah, A. (2010). The 3P model: A general theory of subjective wellbeing. Journal of Happiness Study, 3, 433-440. https://doi.org/ 10.1007/s10902-010-9223-9

Hartnett, M., George, A. S., \& Dron, J. (2010). Examining motivation in online distance learn environments: Complex, multifaceted, and situationdependent. International Review of Research in Open and Distance Learning, 20-38. https://doi.org/10.19173/irrodl.v12i6.1 030

Haryono, E. S., Anggraini, H., \& Budiarti. M. (2019). Pendidikan bagi anak berkebutuhan khusus dengan pendekatan mindfulness teaching. Prosiding Seminar Nasional \& Call Paper, 262-266.

Hefferon, K., \& Boniwell, I. (2011). Positive psychology: Theory, research 
and applications. Open University Press.

Hue, M., \& Lau, N. (2015). Promoting well-being and preventing burnout in teacher education: A pilot study of a mindfulness programme for preservice teachers in Hongkong. Teacher Development, 19(3), 381-401. https://doi.org/10.1080/13664530.2015 .1049748

Kabat-Zinn, J. (2003). Mindfulness-based intervention in context: Past, present, and future. Clinical Psychology, Science and Practice, 10, 144-156. https://doi.org/10.1093/clipsy.bpg016

Keng, L. S., Smoski, M. J., \& Robins, C. J. (2011). Effect of mindfulness on psychological health: A review of empirical studies. Clinical Psychological Review, 31(6), 10411056.

https://doi.org/10.1016/j.cpr.2011.04.0 06

Khairani, R. (2007). Prevalensi diabetes mellitus dan hubungannya dengan kualitas hidup lanjut usia di masyarakat. Universa Medicina, 26(1), 18-26.

http://doi.org/10.18051/UnivMed.2007 .v26.18-26

Maharani, A. E. (2016). Pengaruh pelatihan berbasis mindfulness terhadap tingkat stres pada guru PAUD. Jurnal Penelitian Ilmu Pendidikan, 9(2). 100110.

https://doi.org/10.21831/jpipfip.v9i2.1 2919

Myers, A., \& Hansen, C. H. (2002). Experimental psychology, (5th ed.). Wadsworth.

Marsidi, S. R. (2011). Pengaruh program mindfulness teaching terhadap emosi pada guru Sekolah Dasar pelaksana pendidikan inklusi (Tesis tidak diterbitkan). Universitas Gadjah Mada Yogyakarta.

Nashori, F., Nugraha, S. P., \& Wulandari, E. D. (2019). Insomnia-cognitive behavior therapy to improve the subjective well-being of university students. Psychology and Education an Interdisciplinary Journal, 56(2), 10-18.

Nugraheni, A. (2017). Program guru bahagia untuk meningkatkan kesejahteraan subjektif guru honorer (Tesis tidak diterbitkan). Universitas Gadjah Mada Yogyakarta.

Pavot, W., \& Diener, E. (1993). Review of the satisfaction with life scale. Psychological Assessment, 5(2), 164172.

Poulin, P. A., Mackenzie, C. S., Soloway, G., \& Karayolas, E. (2008). Mindfulness training as an evidencedbased approach to reducing stress and promoting wellbeing among human services professionals. International Journal of Health Promotion \& Education, 46(2), 35-43. https://doi.org/10.1080/14635240.2008 .10708132

Puspitasari, D. A., \& Handayani, M. M. (2014). Hubungan tingkat self-efficacy guru dengan tingkat burnout pada guru sekolah inklusi di Surabaya. Jurnal Psikologi Pendidikan dan Perkembangan, 3(1), 59-68.

Rahman, A. A., Permana, L., \& Hidayat, I. N. (2019). Peran mindfulness dalam meningkatkan behavioral self control pada remaja. Jurnal Ilmu Perilaku, $3(2)$, 110-117. https://doi.org/10.25077/jip.3.2.110117.2019

Rosada, A. (2015). Efektivitas emphatic love therapy untuk meningkatkan kesejahteraan subjektif dan kesiapan guru di sekolah inklusi (Tesis tidak diterbitkan). Universitas Gadjah Mada Yogyakarta.

Silberman, M., \& Biech, E. (2015), Active learning: A handbook of technique, designs, case examples and tips, (4th $E d$.), Wiley Tomlinson.

Stark, R., Gordon-Burns, D., Purdue, K., Rarere-Briggs, B., \& Turnock, K. (2011). Other parents' perceptions of disability and inclusion in early 
childhood education: Implications for the teachers' role in creating inclusive communities. He Кири The World, 2(4), 4-19.

Stanculescu, E. (2014). Psychological predictors and mediators of subjective well-being in a sample of Romanian teachers. Revista de Cercetare si Interventie Sociala, 46, 36-52.

Thohiroh, H., Novianti, L. E., \& Yudiana, W. (2019). Peranan persepsi dukungan sosial terhadap kesejahteraan subjektif di sekolah pada siswa Pondok Pesantren Modern. Psympathic: Jurnal Ilmiah Psikologi, 6(2), 131-144. https://doi.org/10.15575/psy.v6i2.5323

Utami, M. S. (2009). Keterlibatan dalam kegiatan dan kesejahteraan subjektif mahasiswa. Jurnal Psikologi, 36(2). 144-162.

https://doi.org/10.22146/jpsi.7892
Watson, D., Clark, L. A., \& Tellegen, A. (1988). Development and validation of brief measures of positive and negative affect: The PANAS scales. Journal of Personality and Social Psychology, 54, 1063-1070. http://doi.org/10.1037/00223514.54.6.1063

Widiasmara, N., Nashori, H. F., \& Gusniarti, U. (2013). Pengaruh psikoedukasi "Guru Tahu" terhadap peningkatan pengetahuan dasar guru tentang peserta didik di sekolah inklusi. Jurnal Intervensi Psikologi, $5(1)$, 75-94. http://doi.org/10.20885/intervensipsiko logi.vol5.iss1.art5

Widiasti, I. D. (2013). Tingkat kesiapan sekolah dalam implementasi pendidikan anak berkebutuhan khusus (Studi deskriptif pada Sekolah Dasar inklusi di kota Semarang tahun ajaran 2012/2013) (Skripsi tidak diterbitkan). Universitas Negeri Semarang. 